\title{
Seasonal responses of a fringing reef community to eutrophication (Reunion Island, Western Indian Ocean)
}

\author{
Odile Naim \\ Laboratoire de Biologie marine, Université de la Réunion, 15 avenue René Cassin, 97489 Saint-Denis Cedex, La Réunion (DOM), \\ France
}

\begin{abstract}
Seasonal changes in benthic community composition were investigated on a degraded fringing reef subject to nutrient-enriched submarine groundwater discharge. From December to February (hot season), algae dominate the benthic community, overgrowing scleractinians: $19 \%$ of hard corals died in the studied area, of which $16 \%$ were overgrown by algae (turfs mostly composed of Ceramiales, Dictyosphaeria setchellii and encrusting coralline algae) and $3 \%$ were bleached and subsequently died. In a qualitative assessment, the rhodophyte Gracilaria crassa appeared to be a major factor in the overgrowth and mortality of corals on the reef flat. Algal components displayed strong seasonal variation in abundance and dominance. Changes in the algal community are highly correlated with 2 environmental factors : (1) early onset of intermittent trade winds in March, correlated with replacement of large fleshy algal facies by lithophytic algal facies and (2) calm conditions in November, associated with warming of the waters, correlated with an increase in large fleshy algae capable of overgrowing many substrata. Thus, during the hot season, hydrological conditions cause eutrophic conditions and enhance algal growth while reducing coral vitality. Therefore, this is the most critical period for a coral community growing in eutrophic conditions.
\end{abstract}

\section{INTRODUCTION}

Eutrophication was first recognized as a major problem for coral reefs by Doty (1969), Fishelson (1973) and Banner (1974). Although reefs have one of the highest rates of primary gross productivity per unit biomass, they cannot withstand much nutrient enrichment. Most of the evidence of a direct relationship between nutrient dynamics and production processes comes from eutrophic systems. Eutrophication via nutrient enrichment of the reef waters places the ecosystem at a disadvantage by interfering with its normal functioning. Recently, Bell (1992) made a review of general impacts of eutrophication on coral reef ecosystems, but Smith et al. (1981) first described the biological and physical parameters characterizing a eutrophic reef. Kinsey \& Davies (1979) attributed more than $50 \%$ suppression of reef calcification to phosphate enhancement. Tomascik \& Sander (1985) concluded that water quality affects coral growth rates in eutrophic fringing reefs while Rose \& Risk (1985) demonstrated a correlation between the degree of organic pollution on a reef and an increase in bioerosion and amount of dead coral substratum. In the same year, Pastorok \& Bilyard's (1985) review showed that human sewage is an increasingly common stress for coral reefs and investigations from Maragos et al. (1985) confirm that nutrient excess is a major stress for corals and a stimulant for algal growth. Lewis (1988) described the enhancement of organic production by nutrient enrichment.

In the 1970 s, the reef studied was characterized by flourishing coral communities and the rare occurrence of fleshy algae (Bouchon 1981, Faure 1982). Guillaume et al. (1983) first recorded an obvious degradation of this reef site. Later, Cuet et al. (1988) pointed out that the nutrients in the submarine groundwater discharge (SGD) were derived from anthropogenic sources (due to increased population growth and urbanization of the watershed), and showed that on the reef area subjected to this enriched fresh water, living coral cover is lower while algal cover is increasing. Runoff of terrigeneous water did not occur in the studied reef flat and there was no obvious sedimentation. 
Several investigators have examined community structure by surveying the patterns of occupation of substrata by the major benthic groups (Barnes et al. 1971, Morton 1974, Benayahu \& Loya 1977, Drew 1977, Bradbury et al. 1986, Reichelt et al. 1986, Done et al. 1991). However, the majority of coral reef research to date has been aimed at certain taxonomic levels. Generally, such investigations do not provide information about processes influencing community structure, with few exceptions: Kohout \& Kolipinski (1967) reported that the distribution of benthic organisms in Florida was related to patterns of groundwater discharge. At Aqaba (Red Sea), in phosphate-enriched conditions, Fishelson (1973) and Walker \& Ormond (1982) reported a dramatic increase in algal biomass due to eutrophication while Mergner (1981) described the unrestrained algal growth which rapidly covered the whole reef flat and overgrew coral colonies, particularly the species with small polyps. Furthermore, Smith et al. (1981), Maragos et al. (1985) and Tomascik \& Sander (1987) studied the effect of eutrophication on benthic communities.

In order to clarify the long-term change in scleractinian cover, seasonal nutrient-regulation has been investigated in one of the most degraded areas of La Saline reef, Reunion. The term 'nutrient regulation' was introduced by Atkinson (1988) to describe changes in characteristics of communities brought about by nutrient additions that are not rate processes. Nutrients are ephemeral in space and time in their free state because they are rapidly taken up by the biota (therefore, the influence of a brief but substantial pulse may be felt for years). Therefore, I have tried to assess the effects of eutrophication disturbance and damage by considering the seasonal small-scale alteration within the communities especially within biobuilders and algae.

\section{MATERIALS AND METHODS}

Location and physiography of the reef. The high volcanic island of La Réunion $\left(21^{\circ} 7^{\prime}\right.$ to $19^{\circ} 40^{\prime} \mathrm{S}$, $55^{\circ} 13^{\prime}$ to $61^{\circ} 13^{\prime}$ E) displays narrow (maximal width: $520 \mathrm{~m}$ ) and discontinuous fringing reefs which lie along its dry western coast (Fig. 1). Montaggioni \& Faure (1980) circumstantially described these reefs. From open ocean towards land, the upper part of the reef area studied (Fig. 2) can be divided into 3 parts (according to Battistini et al. 1975): (1) a $190 \mathrm{~m}$ wide reef flat, exposed during low waters, which can be divided into 3 subzones, (a) an outermost very shallow compact reef flat, exposed to high wave-energy, that is composed of a more or less horizontal $60 \mathrm{~m}$ wide platform, (b) an outer shallow reef flat of $30 \mathrm{~m}$ width, made of narrow coral strips and (c) a $100 \mathrm{~m}$ wide inner reef

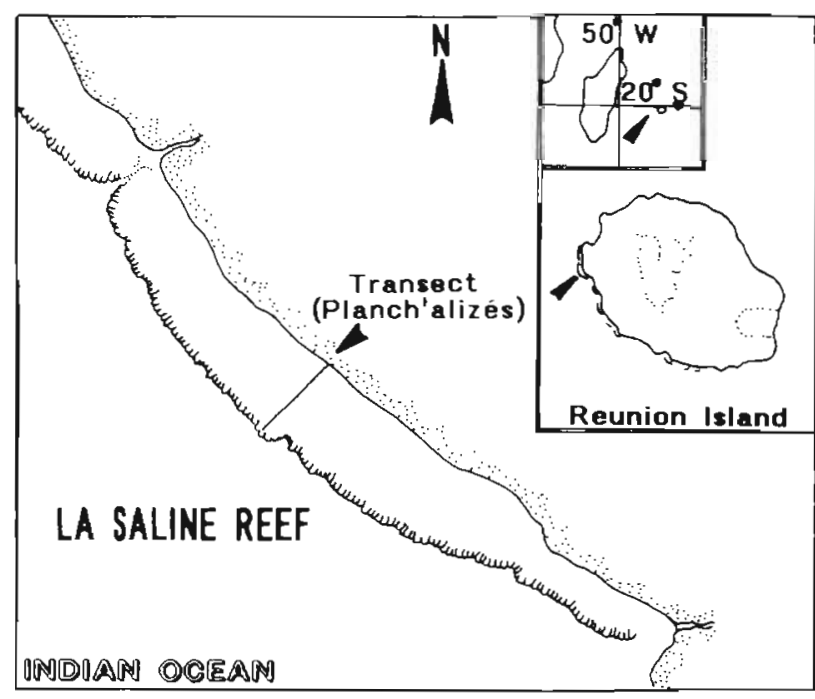

Fig. 1. Location of study area

flat, where corals grow as large transverse strips alternating with narrow and shallow detrital channels; (2) shoreward, a zone of scattered coral heads of $60 \mathrm{~m}$ width, which is mostly composed of branching coral colonies; and (3) a $250 \mathrm{~m}$ wide back reef zone, mainly detrital in nature, which constitutes the deepest part of the reef ( 1 to $1.5 \mathrm{~m})$

Environmental assessment. The seasonal temperature pattern graduates from August, the coldest month, to January, the warmest. Extreme temperatures of reef waters recorded during this study range from $23.5^{\circ} \mathrm{C}$ in May to $31.6^{\circ} \mathrm{C}$ in January. The hydrological regime is primarily a response to the southeast trade winds $(7$ to $11 \mathrm{~km} \mathrm{~h}^{-1}$ ): during the cool season from June to August, the southeast swell (1 to $2 \mathrm{~m}$ amplitude) impinges on most of the coast. During the hot season from December to February, the winds and swells are weak ( $<6 \mathrm{~km} \mathrm{~h}^{-1} ; 0.5 \mathrm{~m}$ maximal amplitude), but occasional cyclones can generate strong whirlwinds (120 to $250 \mathrm{~km} \mathrm{~h}^{-1}$ ) and ocean swells of 4 to $6 \mathrm{~m}$ amplitude. Moreover, the reef can be affected by 5 to $6 \mathrm{~m}$ high swell generated by polar depressions around Marion Island (Roaring Forties), particularly during the austral winter. Thus, the studied area lies in exposed conditions. Tides are semidiurnal and the range, which can be highly modified by swells, varies from 0.1 (neap) to $0.9 \mathrm{~m}$ (spring). The total annual rainfall on the watershed $(570 \mathrm{~mm}$ ) occurs mainly between December and March. Nutrient concentrations of reef waters in the study area (Cuet 1989) and of oceanic waters (Leroy \& Barbaroux 1980) are recorded in Table 1.

Methods. A nutrient-enriched degraded area (Planch'alizés) was chosen according to previous studies (Cuet et al. 1988). A permanent line transect, running from the beach edge to the seaward edge of the reef 
Fig. 2. Sketch of reef studied (modified from Montaggiori \& Faure 1980)

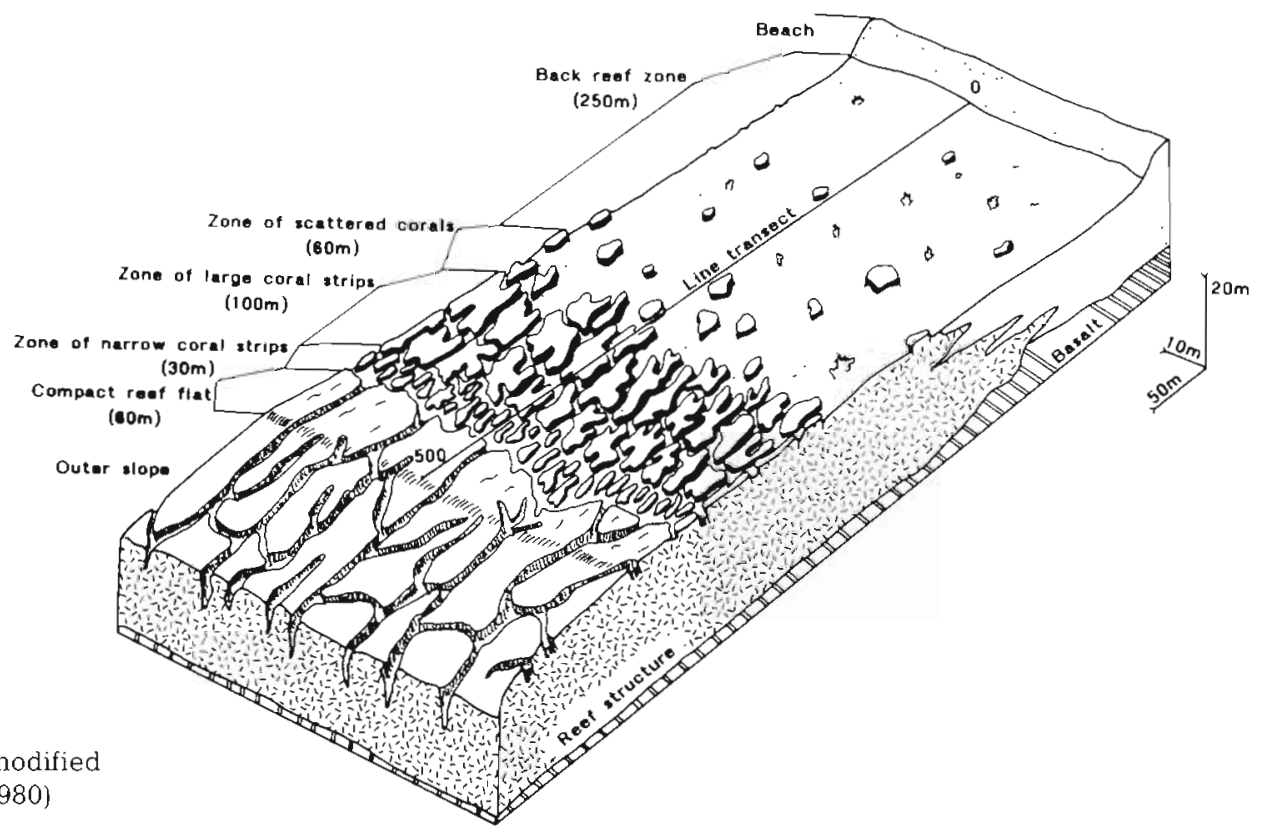

(500 m long; Fig. 2), was based on general reef morphology determined by aerial photographs (it corresponds exactly to Transect $\mathrm{Td}$ studied in Cuet et al. 1988). The percentage of cover by large sessile benthic organisms was assessed (with $5 \mathrm{~cm}$ accuracy, thus smaller species were neglected) along this permanent line transect (steel stakes were placed at $10 \mathrm{~m}$ intervals on the transect). Seasonal sampling was conducted along this transect 4 times a year: in spring 1985 (Nov), in summer 1986 (Feb-Mar; hot and rainy season), in autumn 1986 (Apr-May) and in winter 1986 (July; cold and dry season). In addition, qualitative observations were made on this reef area throughout the year.

The 4 sets of raw data were classified using correspondence factor analysis (Benzecri 1973). The basic principles can be explained as follows: we consider a matrix describing an assemblage $N$ of $X$ observations (e.g. the time periods of sampling) by an assemblage $P$ of $X^{\prime}$ variables (e.g. the benthic community cover in $\mathrm{cm}$ ). A vector can be assigned to every measurement made on every seasonal sample (line transect). At the end of the analysis, the assemblage $N$ is represented by $X^{\prime}$ vectors in a space of $X$ dimensions. To understand the geometrical relationship existing between variable and observation points in multidimensional spaces, we project the vectors on new axes called factor axes or factors. All these defined axes pass through the center of gravity of the set. Factor 1 corresponds to the largest value of variance, Factor 2 to a less large value of variance, and so on.

The factor spaces (i.e. planes) proper to variable points are superimposed graphically as well as mathematically, in order to show relationships between observations, variables and axes. Each point plays a part in defining axes; this property has been termed 'absolute contribution' of point to axis. Reciprocally, each factor axis contributes to the definition of the position of a given point with respect to the center of gravity of

Table 1. Nutrient concentrations in $\mu \mathrm{M}^{-1}$ of oceanic waters in August 1977 and April 1979 (Leroy \& Barbaroux 1980) and reef waters in 1985-86 (Cuet 1989)

\begin{tabular}{|c|c|c|c|c|}
\hline & Groundwater ${ }^{a}$ & Back reef zone waters ${ }^{a}$ & Reef flat waters ${ }^{a}$ & Subsurface oceanic waters ${ }^{b}$ \\
\hline Mean $\mathrm{NO}_{3}^{-}$ & $231 \pm 53$ & $3.23 \pm 0.99$ & $0.96 \pm 0.42$ & $\begin{array}{c}0 \text { to } 0.2 \text { (nitrite }+ \text { nitrate } \text {; winter) } \\
0 \text { (summer) }\end{array}$ \\
\hline $\mathrm{Max} . \mathrm{NO}_{3}^{-}$ & - & $12.2($ Apr 87) & $2.6(\mathrm{Dec} 85)$ & - \\
\hline Mean $\mathrm{PO}_{4}{ }^{3-}$ & $4.05 \pm 0.56$ & $0.36 \pm 0.18$ & $0.33 \pm 0.09$ & $\begin{array}{c}0.2 \text { to } 0.3 \text { (winter) } \\
0.1 \text { (summer) }\end{array}$ \\
\hline Max. $\mathrm{PO}_{4}{ }^{3-}$ & - & $1.6($ Nov 86$)$ & 1.1 (Nov 86 ) & - \\
\hline \multicolumn{5}{|c|}{${ }^{d}$ Cuet (1989); ${ }^{b}$ Leroy \& Barbaroux (1980) } \\
\hline
\end{tabular}


the cluster of projected points ('relative contribution' of axis to point). The values of these contributions vary within the range 0 to 1 . Distinct groupings of points can be differentiated on the basis of the values of relative contributions. The boundary of each grouping embodies both the sample and the variable points, which are spatially defined by a relative contribution higher than 0.10 . Thus, the precise location of each group is statistically significant with respect to factor axes.

\section{RESULTS}

\section{Nature of substrata and coral cover}

The prevalent nonliving substrata along the transect are rubble ( $44 \%$ of the total substratum), sand ( $25 \%$ ) and dead reef surface $(18 \%)$. Living substrata are formed by scleractinians $(5 \%)$ and sponges $(2 \%)$ or encrusting red algae (4\%) (Fig. 3). The reef flat is made up of $47 \%$ of dead substratum. Living corals represent $15 \%$ of the coral strips zone while the seaward compact reef flat is almost devoid of scleractinians $(2 \%$ of cover). The zone of scattered coral heads shows practically the same relative cover of rubble and sand but with an increase in living coral cover and in substrata covered with red algal crusts. The back reef zone is covered with white sand (36\%) or reef rubble $(59 \%)$, that can be partly overlaid by calcareous algal nodules, occurring mostly along the shoreline. Scattered over this surface are patches of the encrusting sponge Cliona inconstans $(2 \%)$ and clumps of hard substratum ( $2 \%$ ), formed half by living corals and half
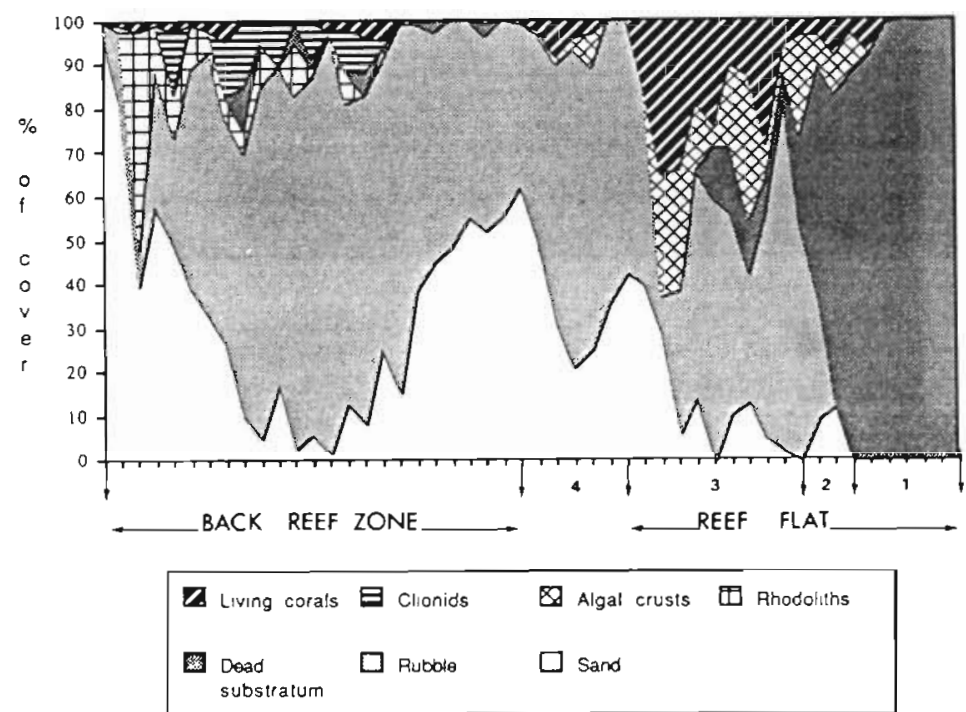

Fig. 3. Percent cover of different substrata along the transect. 1: compact reef flat; 2 : zone of narrow coral strips; 3 : zone of large coral strips; 4: scattered corals zone

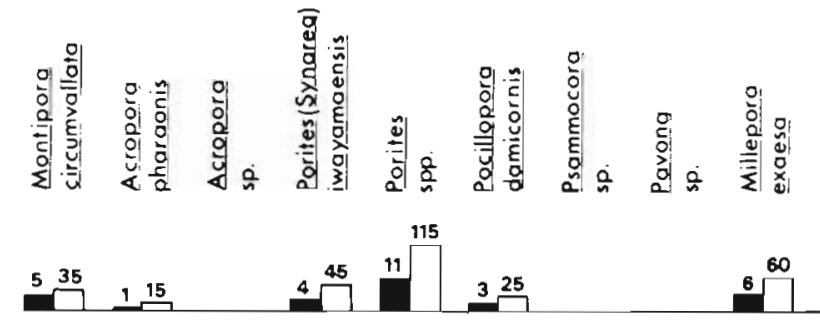

BACK REEF ZONE $(250 \mathrm{~m})$
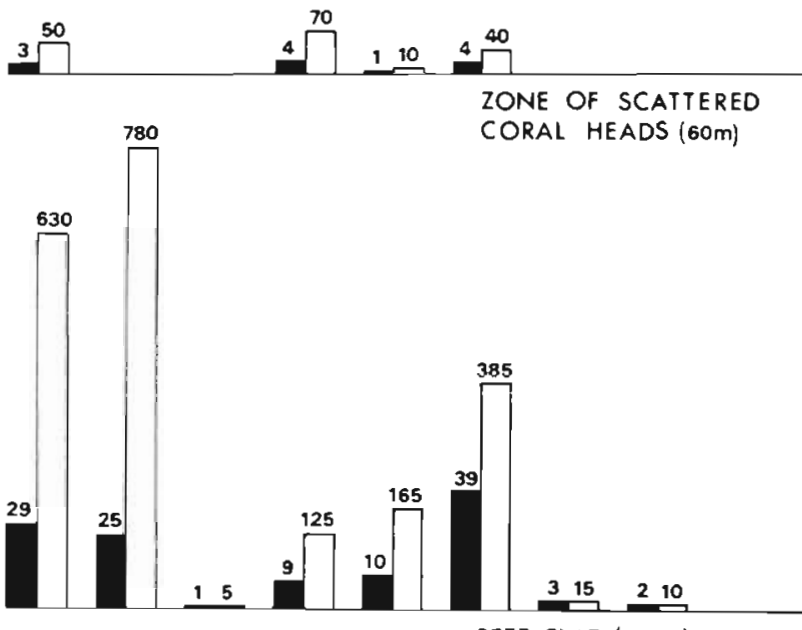

REEF FLAT $(190 \mathrm{~m})$

Fig. 4. No. of coral colonies and cover $(\mathrm{cm})$ of living coral species in the different geomorphological zones in November 1985

by dead substratum. Most of these clumps do not emerge at low tide.

At the beginning of the study (November 1985), 160 colonies of living corals were counted along the line transect (Fig. 4). 28.7\% of the colonies were Pocillopora damicornis, $24.3 \%$ were Porites spp. (10.6\% Porites (Synaraea) iwayamaesis), $23.2 \%$ Montipora circumvallata and $16.8 \%$ were Acropora pharaonis. In terms of surface cover, A. pharaonis and $M$. circumvallata, each of which form large patches, are dominant with 30.9 and $27.7 \%$ respectively of the total living coral cover. Porites spp. represent $20.6 \%(9.3 \%$ by $P$. (S.) iwayamaensis) and Pocillopora damicornis $17.5 \%$ respectively.

\section{Composition of dominant algal communities}

The dominant algae recorded on the transect were classified into 5 groups: (1) Bluegreen algae (cyanophytes) appeared as filaments (mostly Nodularia sp. and Lyngbya sp., accompanied by Phormidium sp.) as well as thick thalli (Schizothrix sp.). (2) Algal turfs 
were composed of dominant filamentous red algae (Ceramiales) associated with the phaeophytes Ectocarpales and Sphacelariales (Payri 1985). These lawns were actively defended by the damselfish Stegastes nigricans as its territory. (3) Fleshy algae which are mainly composed of phaeophytes (Padina spp., Dictyota divaricata, Turbinaria ornata) and rhodophytes (Acanthophora spicifera, Gracilaria crassa, Digenia simplex and Hypnea sp.). Foliose rhodophytes are poorly developed and the few that occurred were mainly obscured in shaded crevices. Chlorophytes were subordinate (Dictyosphaeria setchellii and Caulerpa racemosa var. peltata). (4) Coralline turfs were mostly composed of Jania sp. (Payri 1985). (5) Calcareous red algal crusts were composed mostly of Porolithon onkodes (Payri 1985) which occurred as a cement pavement. Rhodoliths were not taken into account, their occurrence along the transect being governed chiefly by the current regime rather than by seasonal variations.

These algal communities displayed important seasonal variations in abundance and dominance (Fig. 5). Some classical trends can be inferred; total cover of algae is highest in the hot season $(52 \%$ of the total substratum) and lowest in the winter (17\%). From spring to autumn, the fleshy algae are dominant; the coralline turf cover increases in autumn and winter. The reef flat displays a relatively constant and high algal cover (almost $50 \%$ of the substrata available is covered with algae), while on the back reef zone the algal cover varies from $<10 \%$ in winter to $>60 \%$ in summer (Fig. 6). The lowest annual mean algal cover $(<5 \%)$ characterizes the zone of scattered coral colonies and the highest ( $41 \%$ ), the outer zone of narrow coral strips.

The distributional pattern of the 5 groups of algae along the transect is not homogeneous in space and time. The groups of algae display seasonal successional patterns across the reef (Fig. 7).

\section{Factors influencing the variation in algal communities}

In order to obtain an accurate differentiation of the seasonal variations in algal abundance for the different
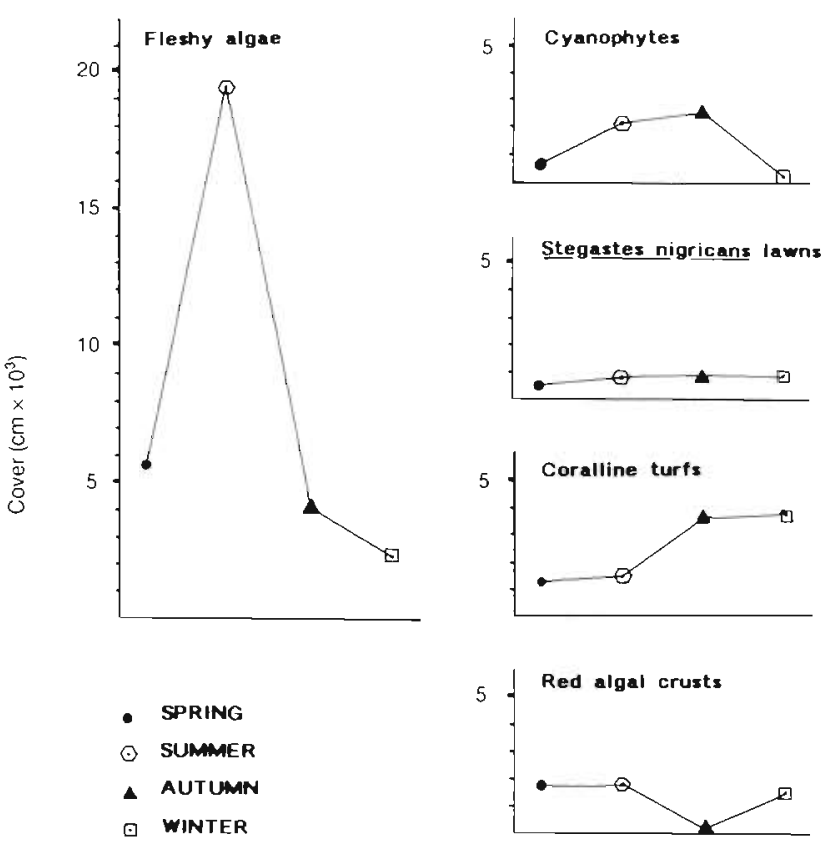

Fig. 5. Seasonal variation in cover of the 5 dominant groups of algae

morphological zones of the reef, factor analysis was applied to the dominant algal groups and species. A first factor analysis was performed from a data matrix composed of 4 observations, the 4 time periods (seasonal) and 28 variables (groups and species of algae, expressed in percent cover in the different zones; Table 2). The variables and observations were projected onto the same plane of factor axes.

Only Axes $1 \& 2$ were taken into account first, since they explain $88 \%$ of the variance (Fig. 8). Factor 1 (F1), accounting for $49 \%$ of the variance, is largely controlled by the opposition between algal communities occurring in autumn and summer, while Factor 2 (F2), accounting for $39 \%$ of the variance, depends mainly upon the opposition between algal communities occurring in spring and summer. Thus, 3 groups of algae are highlighted in the plane defined by the 2 factors.
Fig. 6. Seasonal variation in percent cover of algae in the different geomorphological zones. 1: compact reef flat 2: zone of narrow coral strips; 3: zone of large coral strips; 4: scattered corals zone

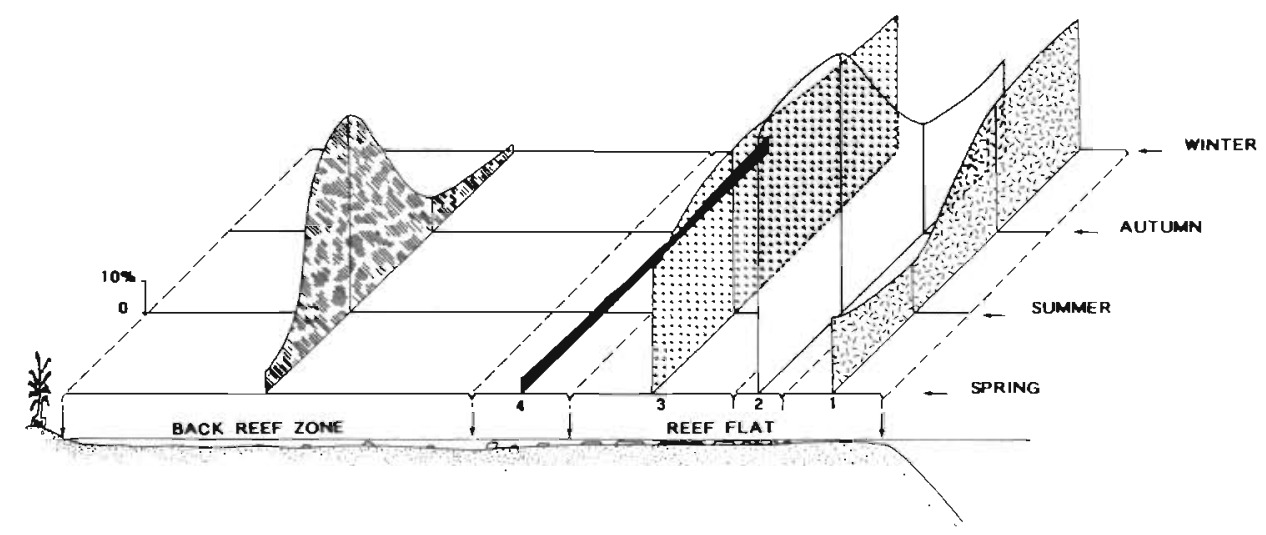



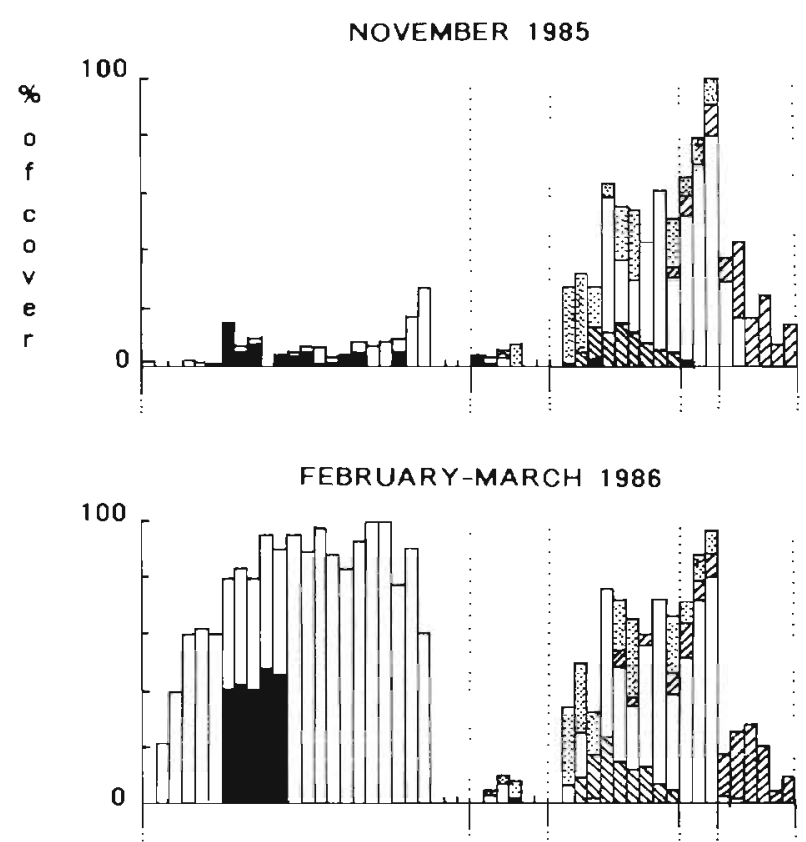

APRIL-MAY 1986

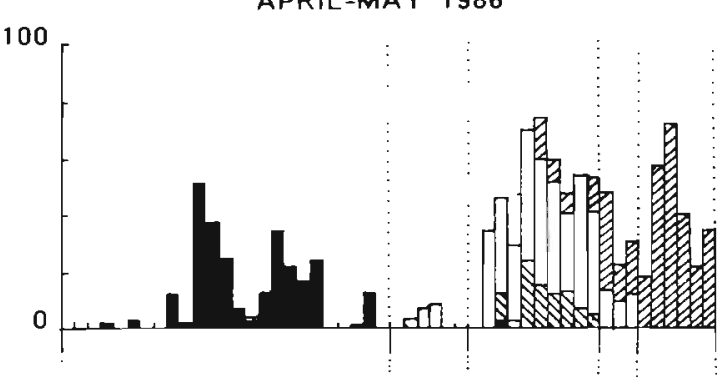

JULY 1986
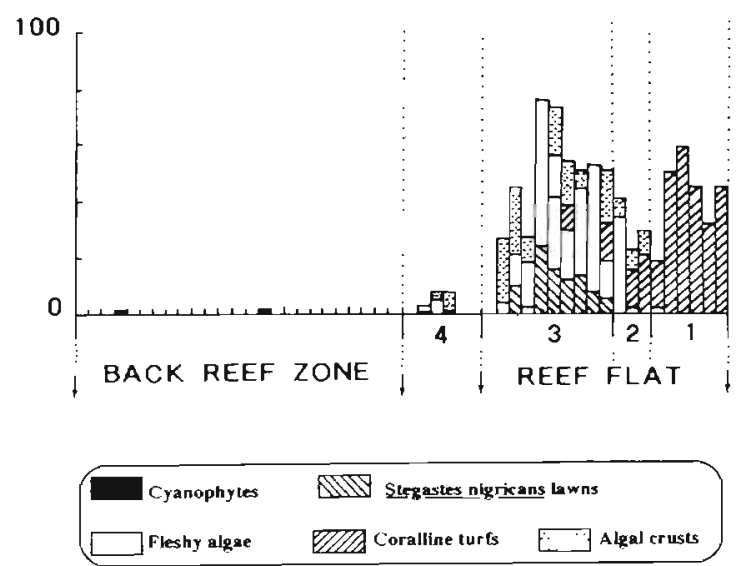

Fig. 7. Seasonal variation in percent cover of the 5 dominant groups of algae along the transect. 1 : compact reef flat; 2: zone of narrow coral strips; 3: zone of large coral strips; 4. scattered corals zone

The group which clearly characterizes the autumn is composed of coralline turfs, turfs of Stegastes nigricans territories and Turbinaria ornata on the coral-built zones. This first group is in opposition to a second algal group occurring in summer, including Dictyota divaricata, Gracilaria crassa on the reef flat and Caulerpa racemosa var. peltata, Acanthophora spicifera and Hypnea sp. on the back reef zone. The third group is strongly characteristic of spring (September to November): $D$. divaricata on the compact reef flat and Amphiroa rigida on the reef flat composed of coral strips. This community is in opposition to the occurrence, in summer, of Dictyosphaeria setchellii on the reef flat and A. spicifera and Hypnea sp. on the back reef zone.

The third factor (F3), accounting for $11 \%$ of the total variance, opposes (within the factor space $F 1$ and F3) the winter observation (June to August), which is characterized by encrusting red algae on the reef flat, to the autumnal observation (March to May), concerned mainly with Digenia simplex and subordinately with Turbinaria ornata in the same zone (Fig. 9). Coralline turfs occurring throughout the reef in winter are also moderately opposed to the fleshy algae which highly characterize summer (December to February). Fig. 10, representing the factor space F2 and F3, highlights the 4 opposed algal groups characterizing the 4 different seasons.

Changes in dominant algal communities depending mainly upon F1 are correlated with the setting-up of the early intermittent trade winds and the cooling of the water in March (between summer and autumn), and more generally to the differential conditions between spring and summer versus autumn and winter periods. The variance explained by $\mathrm{F} 1$ is relatively low because of the presence of perennial algae like Gracilaria crassa and Stegastes nigricans turfs which present a relatively constant cover throughout the year. Modifications within algal communities also mainly depend upon F2 which, conversely, is correlated with the warming of waters and appearance of very calm hydrodynamic conditions between spring and summer.

These quantitative data and annual qualitative observations of algal dynamics lead to the following interpretation: (1) In summer (from December to February), the algal layer becomes denser because of the seasonal growth of macroscopic fleshy algae. On the reef flat, the extensive dead surfaces are invaded by a rich growth of macroscopic algae. Lying at the base of large coral strips, patches of perennial Gracilaria crassa show a high increase in standing crop; the plants are attached to dead Acropora spp. rubble (hydrological conditions may not allow the development of extensive free-living populations) and are predominant for most of the year. Located round the coral strips, mostly on dead Acropora spp. thickets, the perennial Stegastes nigricans turfs also show a 
Table 2. Seasonal coverage [ $\mathrm{cm}\left(10 \mathrm{~m}^{-1}\right)$ of line transect] and relative contributions (RC) to factor axes of groups and species of algae. BR: back reef zone; SCZ: scattered corals zone; LCSZ: zone of large coral strips; NCSZ; zone of narrow coral strips; CRF: compact reef flat

\begin{tabular}{|c|c|c|c|c|c|c|c|c|}
\hline Species & Zone & Spring & Summer & Autumn & Winter & $\mathrm{RC} / \mathrm{F} 1$ & $\mathrm{RC} / \mathrm{F} 2$ & $\mathrm{RC} / \mathrm{F} 3$ \\
\hline Acanthophora spicifera (ACANTH) & $\mathrm{BR}$ & 0 & 429 & 0 & 0 & 0.61 & 0.38 & 0.01 \\
\hline Amphiroa fragilissima (AMPH) & LCSZ & 2 & 0 & 0 & 0 & 0.05 & 0.93 & 0.02 \\
\hline Amphiroa fragilissima (AMPH) & NCSZ & 50 & 13 & 10 & 3 & 0.06 & 0.85 & 0.08 \\
\hline Caulerpa racemosa v peltata (CAUL) & BR & 14 & 45 & 0 & 0 & 0.89 & 0.07 & 0.03 \\
\hline Coralline turfs (COR) & BR & 2 & 0 & 1 & 2 & 0.30 & 0.47 & 0.23 \\
\hline Coralline turfs (COR) & CRF & 163 & 133 & 383 & 400 & 0.91 & 0.01 & 0.08 \\
\hline Coralline turfs (COR) & LCSZ & 0 & 14 & 42 & 42 & 0.75 & 0.18 & 0.06 \\
\hline Coralline turfs (COR) & NCSZ & 3 & 70 & 208 & 218 & 0.75 & 0.17 & 0.07 \\
\hline Cyanophytes (CYAN) & $\mathrm{BR}$ & 25 & 0 & 86 & 0 & 0.50 & 0.00 & 0.50 \\
\hline Dictyosphaeria setchellii (SETCH) & LCSZ & 11 & 30 & 20 & 19 & 0.04 & 0.95 & 0.00 \\
\hline Dictyota divaricata (DICT) & $\mathrm{CRF}$ & 23 & 0 & 0 & 0 & 0.05 & 0.93 & 0.02 \\
\hline Dictyota divaricata (DICT) & LCSZ & 17 & 48 & 0 & 0 & 0.92 & 0.07 & 0.03 \\
\hline Dictyota divaricata (DICT) & NCSZ & 155 & 586 & 0 & 0 & 0.86 & 0.11 & 0.03 \\
\hline Digenia simplex (DIG) & $\operatorname{LCSZ}$ & 9 & 12 & 9 & 0 & 0.08 & 0.00 & 0.91 \\
\hline Gracilaria crassa (GRAC) & LCSZ & 179 & 207 & 171 & 190 & 0.67 & 0.03 & 0.30 \\
\hline Gracilaria crassa (GRAC) & $\operatorname{NCSZ}$ & 620 & 766 & 581 & 638 & 0.59 & 0.01 & 0.40 \\
\hline Hypnea sp. (HYPN) & $\mathrm{BR}$ & 0 & 97 & 0 & 0 & 0.61 & 0.38 & 0.01 \\
\hline Padina sp. (PAD) & $\mathrm{BR}$ & 21 & 0 & 0 & 0 & 0.05 & 0.93 & 0.02 \\
\hline Padina sp. (PAD) & $\mathrm{CRF}$ & 43 & 0 & 0 & 0 & 0.05 & 0.93 & 0.02 \\
\hline Padina sp. (PAD) & $\operatorname{LCSZ}$ & 4 & 0 & 0 & 0 & 0.05 & 0.93 & 0.02 \\
\hline Padina sp. (PAD) & NCSZ & 463 & 0 & 0 & 0 & 0.05 & 0.93 & 0.02 \\
\hline Red algal crusts (CRUST) & LCSZ & 149 & 149 & 0 & 122 & 0.35 & 0.19 & 0.46 \\
\hline Red algal crusts (CRUST) & $\mathrm{NCSZ}$ & 83 & 83 & 0 & 78 & 0.25 & 0.16 & 0.59 \\
\hline Red algal crusts (CRUST) & $\mathrm{SCZ}$ & 23 & 21 & 0 & 20 & 0.24 & 0.23 & 0.53 \\
\hline Stegastes nigricans (LAWN) & LCSZ & 58 & 87 & 87 & 87 & 0.76 & 0.17 & 0.07 \\
\hline Turbinaria ornata (TURB) & LCSZ & 3 & 10 & 159 & 18 & 0.61 & 0.07 & 0.32 \\
\hline Turbinaria ornata (TURB) & $\mathrm{NCSZ}$ & 7 & 18 & 111 & 5 & 0.48 & 0.07 & 0.44 \\
\hline Turbinaria ornata (TURB) & $\mathrm{SCZ}$ & 0 & 0 & 20 & 1 & 0.59 & 0.05 & 0.36 \\
\hline
\end{tabular}

Fig. 8. Plot of factor axes 1 \& 2. Both observations (seasons) and variables (algae) are plotted simultaneously. AC: absolute contribution of observations to factor axes. Abbreviations and relative contributions of variables to factor axes in Table 2

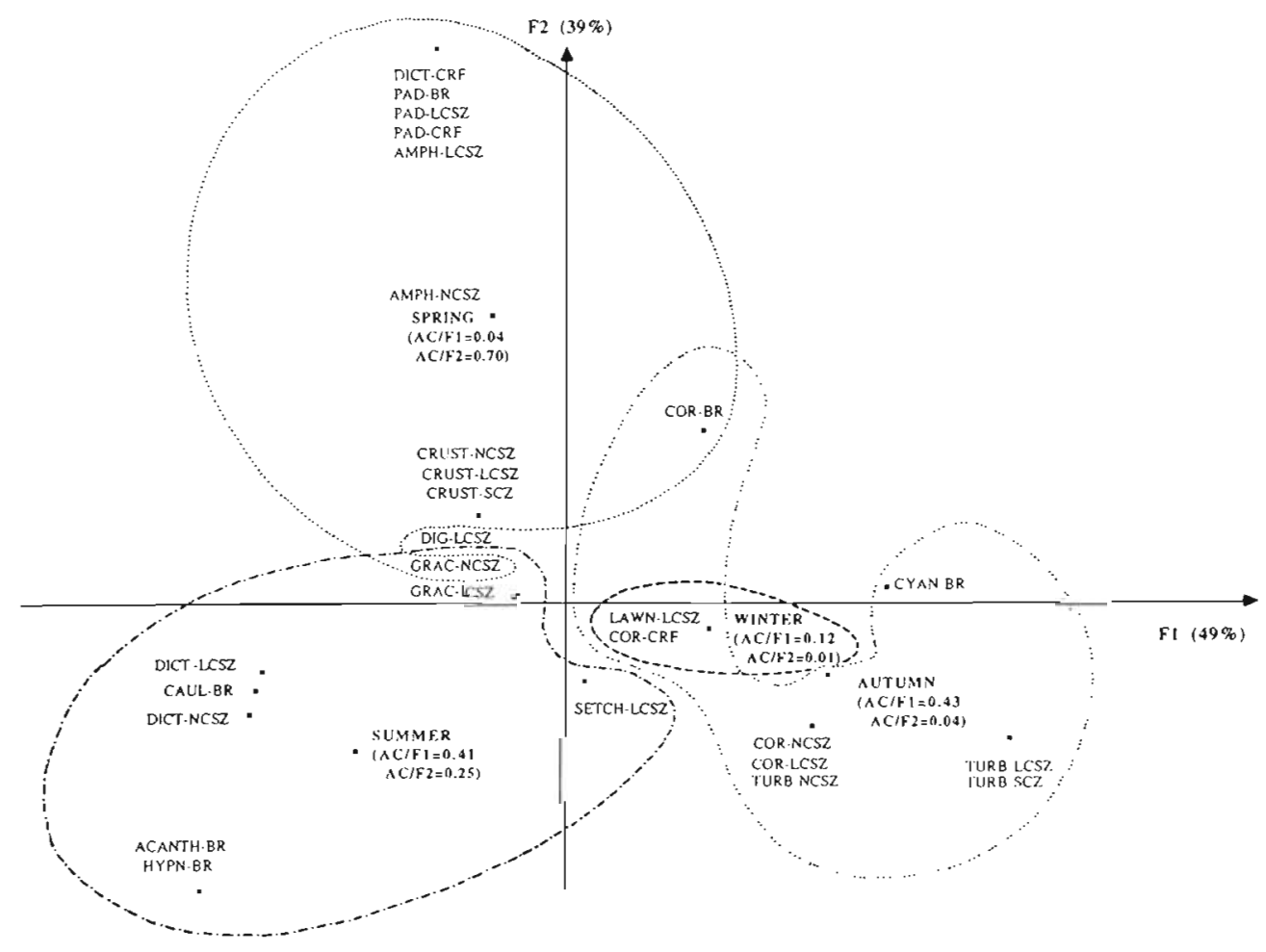




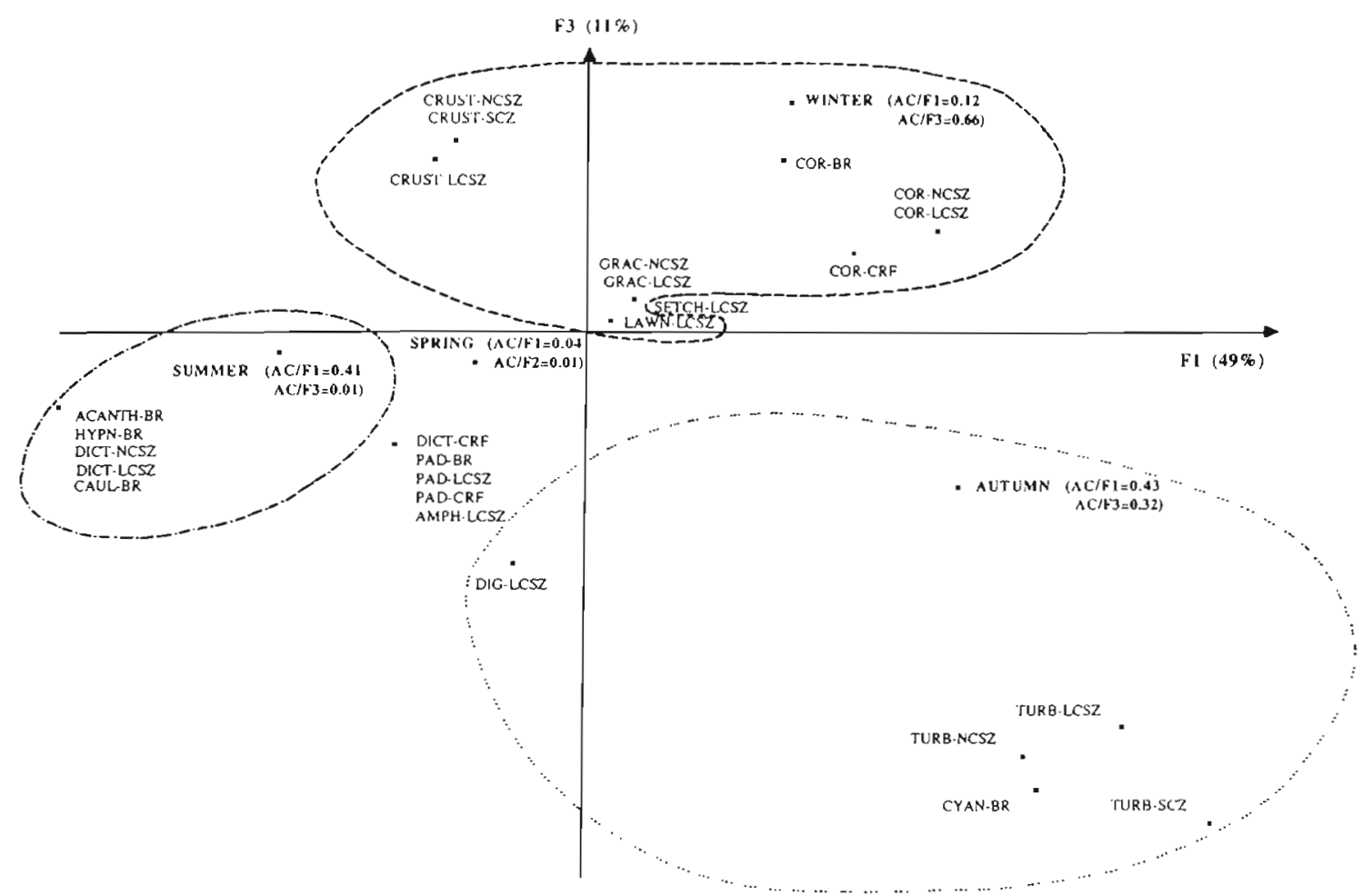

Fig. 9. Plot of factor axes 1 \& 3. Both observations (seasons) and variables (algae) are plotted simultaneously. AC: absolute contribution of observations to factor axes. Abbreviations and relative contributions of variables to factor axes in Table 2

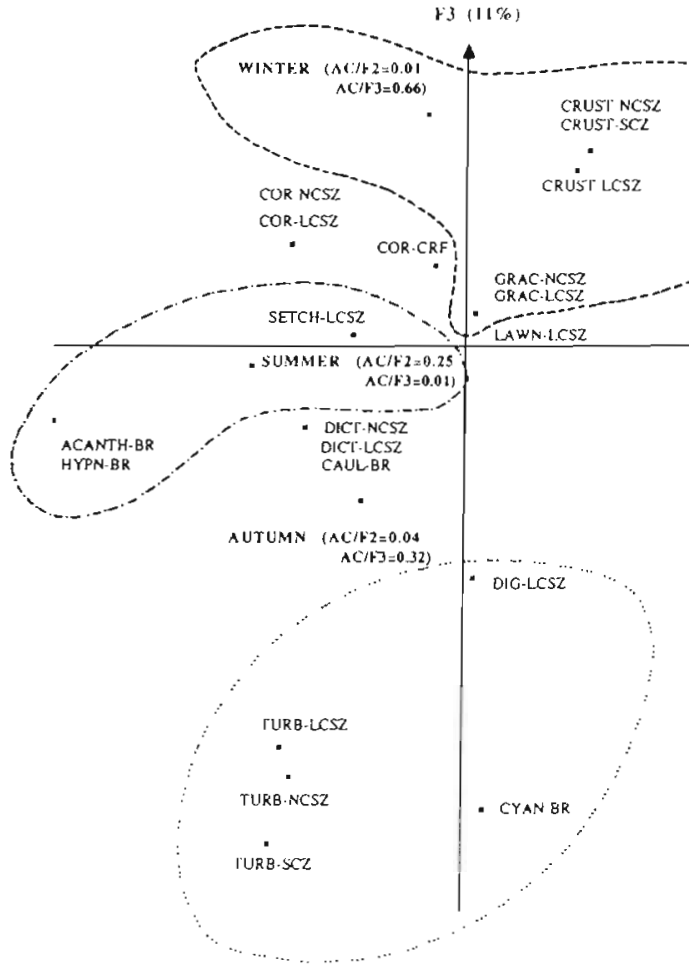

very high enhancement of growth; most of the steel stakes located within the territories were covered by a $1 \mathrm{~cm}$ layer of these turfs during a 1 mo interval
(February). While encrusting coralline algae occur on the upper part of the coral patches, they tend to be overgrown by noncalcareous species, particularly 
Lobophora variegata and Dictyosphaeria setchellii. Otherwise, on the reef flat, the cyanophyte Lyngbya majuscula can be very abundant within the scleractinian skeletons. Mats of calcareous red algal turfs become sparser and patchier on the exposed outer compact reef flat.

A thick lawn of the filamentous form of Acanthophora spicifera covers the entire back reef zone, including small scleractinian colonies (the earlier occurrence of a thin $A$. spicifera mat was noted on 25 October). Some of the back reef zone forms are sanddwelling siphonaceous green algae like Caulerpa racemosa var. peltata while Boergesenia forbesii (early thalli appeared in mid-November) is collected on shingle or shells. Away from the line transect, thick mats of a blue-green algae Schizothrix sp. invades the A. spicifera lawn in some places, then forming a $15 \mathrm{~cm}$ thick and dense carpet covering the whole back reef zone. Near the base of the beach, shingle is colonized by ephemeral filaments of Enteromorpha sp. while a red-brown fur of Hypnea sp. occurs on fragments subjected to occasional movement.

(2) At the beginning of autumn (March), trade wind swells remove lumps of Gracilaria crassa patches from the reef flat. These free-floating thalli are exported out of the reef, or if not, they become rapidly detained by dead acroporid rubble heaps or by living Acropora spp. branches. The nonemerging reef-flat flora is predominantly perennial (Stegastes nigricans turfs, G. crassa) and algae inhabiting the upper emerging strips are largely lithophytes. Some, like Turbinaria ornata, grow rapidly from persistent holdfasts and branches during autumn and cover very large surfaces. In this season, on a falling tide, the buoyed, dome-shaped specimens of $T$. ornata are often the first algae to emerge over the reef flat. They totally cover the eroded upper part of large coral strips and thus the encrusting coralline algae. Some of the $T$. ornata and Digenia simplex thalli are heavily epiphytized by $S$. nigncans turfs when they are settled close to the latter's territories. Thus, by shading or by mechanical sweeping action of their wave-moved thalli, they aid the necrosis of the living coral tissue surrounding the holdfasts. The thick lawn of Acanthophora spicifera covering the back reef zone had already entirely disappeared after cyclones or big swells.

(3) F3, less important for the algal communities, is correlated with the establishment of a stable trade wind mode between autumn and winter (in June) and consequently with the influence of constantly agitated and cool waters on the reef. In winter, on the reef flat, the coralline turf coverage become more conspicuous as the large fleshy algae decline but remain present. On the other hand, fleshy algae are worn off the back reef zone, leaving only rare coralline turfs.

\section{Seasonal changes in coral communities}

During the hot season (February 1986), 13\% of the colonies of hard corals on the line transect were dying: $11 \%$ of the colonies were overgrown by algae and $2 \%$ bleached (Fig. 11). The data obtained in autumn confirmed the mortality of these dying coral colonies. Stegastes nignicans turfs, Dictyosphaeria setchellii thalli and encrusting red algae completely overgrew the affected colonies. Bleached corals did not recover. No additional mortality was observed either in April-May or in July.

This mortality corresponds to $19 \%$ of the total coral cover on the transect. The dying corals were not distributed homogeneously along the line transect: $97 \%$ of the mortality was observed in the zone of large coral strips between 320 and $400 \mathrm{~m}$ from the shoreline, which corresponds to $28 \%$ of the coral community distributed within this $80 \mathrm{~m}$ interval (Fig. 12). Several species were affected in this particular zone: $30 \%$ of Porites spp., $29 \%$ of Acropora pharaonis and $15 \%$ of Montipora circumvallata coverage were colonized by Stegastes nigricans turfs. Between the turf filaments very densely scattered on the $M$. circumvallata colonies (the filaments are in fact attached to dead corallites), it was still possible to observe living coral tissue, hidden by the wavemoved filaments. Moreover, $40 \%$ of Porites spp. and $3 \%$ of $M$. circumvallata were overgrown by Dictyosphaeria setchellii and $7 \%$ of $A$. pharaonis by encrusting red algae. In these last cases, it was obvious that the small $D$. setchellii cushions and the encrusting algae were overgrowing the living tissue of the scleractinians. In all, bleaching affected $8 \%$ of
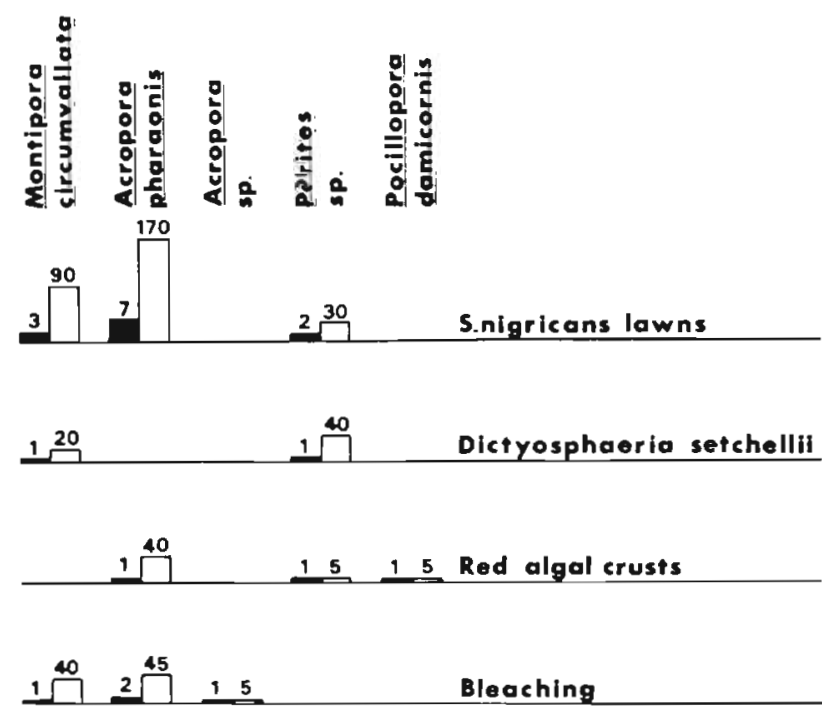

Fig. 11. Coral colonies and cover (cm) of dying coral species in February 1986 and their different factors of stress 


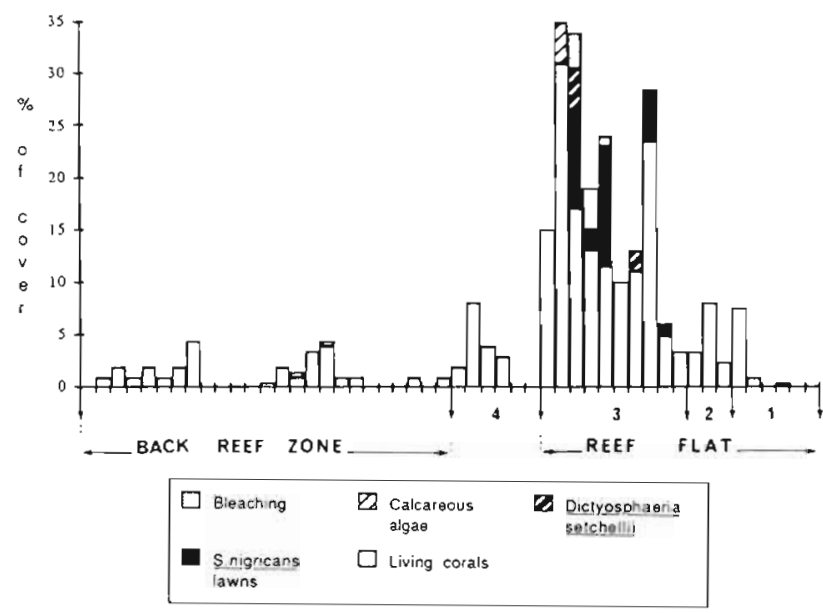

Fig. 12. Living and dead coral coverage along the transect in autumn. Causes of mortality of dead coral are indicated

A. pharaonis and $7 \%$ of $M$. circumvallata. None of the 39 colonies of Pocillopora damicornis or of the 3 colonies of $P$. (S.) iwayamaensis were affected in this $80 \mathrm{~m}$ interval. On the whole transect, $P$. damicornis showed only $1 \%$ of cover mortality and $P$. (S.) iwayamaensis suffered no mortality

During the qualitative survey, Montipora sp. and Acropora pharaonis colonies, located besides the line transect, have been observed to be totally overgrown by very large and dense Gracilaria crassa mats $(50 \mathrm{~cm}$ large, $20 \mathrm{~cm}$ thick at least).

\section{DISCUSSION}

\section{Level of degradation of the reef}

During the 1970s, in spite of the large influence of submarine groundwater input on La Saline reef, coral communities were highly developed and diverse (Faure 1982). Faure's (1982) study, conducted in the early seventies, reported $50 \%$ of coral cover on the outer compact reef flat ( 45 species of corals), $50 \%$ of cover on the inner reef flat (50 species) and 20 to $30 \%$ of cover on the back reef zone (39 species). In 1976-77, Bouchon (1981) reported $50 \%$ of coral cover on the reef flat ( 24 species) and $2.5 \%$ on the back reef zone (35 species). In the present study (1985-86), living corals merely represented $11 \%$ of the substratum on the reef flat (with only $1.5 \%$ on the outer compact reef flat) and $3 \%$ on the back reef zone. Thus, this present study demonstrates the decrease in coral cover observed on La Saline reef. Although an algal belt was noticed on the outer grooved zone of the reef flat during the hot season (December to February), an alarming extension of fleshy algae and an increase in cover of clionids were not recorded on the reef before the end of the seventies (Bouchon \& Bouchon-Navaro 1981, Faure 1982), nor was pronounced coral degradation reported before 1983 (Guillaume et al. 1983, Payri 1983)

\section{Causes of degradation}

Groundwater discharge onto coral reefs was first recognized by Johannes (1980) and Lewis (1985, 1987). On the studied reef, nutrients are mostly issued from submarine groundwater discharge (Cuet et al. 1988, Cuet 1989). Although mean values of $\mathrm{NO}_{3}{ }^{-}$and $\mathrm{PO}_{4}{ }^{3-}$ in the reef waters were not high during the biological study (Table 1, Cuet 1989), it must be emphasized that maximum values of $\mathrm{NO}_{3}^{-}$reached $3.7 \mu \mathrm{M}$ in the reef flat waters (May 1985) and $7.1 \mu \mathrm{M}$ in the back reef zone (January 1986) while $\mathrm{PO}_{4}{ }^{3-}$ concentrations reached $1.1 \mu \mathrm{M}$ on the reef flat and $1.6 \mu \mathrm{M}$ on the back reef zone (November 1986) (Cuet 1989). Given N-rich $\mathrm{SGD}, \mathrm{a} \mathrm{PO}_{4}{ }^{3-}$ enrichment can initiate eutrophication problems (D'Elia et al. 1981). Phosphate concentrations are recognized to influence the development of scleractinians: concentrations of about $0.1 \mu \mathrm{M}$ define oligotrophic waters (Crossland 1983), favourable to reef calcification. Waters with concentrations $\geq 1 \mu \mathrm{M}$ are eutrophic (Smith et al. 1981).

By synthesizing evidence from a wide variety of sources, Hallock \& Schlager (1986) postulated that coral reefs are so highly adapted to nutrient-deficient conditions that any increase in nutrient availability can be detrimental to the system. However, Tomascik \& Sander (1985) concluded that although coral growth is negatively correlated with nitrate and phosphate, other environmental variables, such as chronic turbidity, cause growth decrease of corals. Because sediment loading is very low at the study site (Bouchon \& Bouchon-Navaro 1981), the drastic decline of the scleractinian assemblages observed here may be tentatively ascribed to nutrient enrichment of the reef waters (Cuet et al. 1988).

In spite of no significant seasonal variations in nutrient concentrations in the studied reef (Cuet 1989), coral overgrowth has been observed only in summer or the hot season. According to Hallock's (1988) definitions, the studied reef is an example of a mesotrophic system, tending to be eutrophic during summer. As the term eutrophication has become quite subjective in meaning, I refer to a situation (the hot season) where environmental factors favour a sufficient supply of nutrients from flowing waters to support high growth, maintenance and accumulation of algae that are prejudicial to corals. 


\section{Seasonal variation in the composition of the algal community}

Changes within the algal communities are highly correlated with: (1) trade winds inducing high-energy conditions and cooling of the waters on the reef, probably causing the replacement of large fleshy algal facies settled during the warm season by lithophytic algae such as Turbinaria ornata, Digenia simplex and coralline turfs which are more heavily attached to the substratum; (2) warming of the waters in November and the setting-up of calm hydrological conditions which lead to standing reef waters and correspond with the development of large fleshy algal facies which overgrow all types of substrata; (3) less important for the algal community, the setting-up of a permanent trade wind regime in June, constantly agitating and cooling the reef waters. This period is characterized by the disappearance of the last $T$. ornata from the reef flat and the increased conspicuousness of the coralline turf coverage on the outer compact reef flat.

During the hot season, abundant and ephemeral facies of large phaeophytes are observed on the Great Barrier Reef (Cribb 1973), in Guam (Tsuda 1974), in Moorea (Payri 1987) and in Mauritius (Faure 1982). On La Réunion Island, before the 1980s, the phaeophytes formed only an outer narrow algal belt and were extremely scarce on non-nutrient-enriched reefs (Faure 1982). Such was the case for La Saline reef. But evidence from the present study suggests that, from December to February, the algal community controls the reef mainly by covering more than $50 \%$ of the area and overgrowing scleractinians ( $16 \%$ of coral cover). Five algae have been observed killing living corals, either by overgrowing or by choking: Stegastes nigricans turfs, Gracilaria crassa, both the most injurious to scleractinians, then Dictyosphaeria setchellii, encrusting red algae and Acanthophora spicifera. Moreover, from March to May, the density of attached algae increased (Turbinaria ornata and Digenia simplex), the macrophytes being covered by filamentous algae. Then, these macrophytes $(\varnothing=15$ to $20 \mathrm{~cm}$ for $D$. simplex) move their bolt-foot around and sweep the nearest polyps, causing further stress to corals.

Because of its rapid growth, Gracilaria crassa can invade its living hosts: in April, free-floating thalli are often detained by the base branches of Acropora sp. colonies and, during the next hot season, they rapidly overgrow entire colonies and kill them by blocking light and exchanges. It is interesting to mention that Banner (1974) reported massive growth of Gracilaria $\mathrm{sp}$. on the south of Coconut Island (Kaneohe Bay) related to sewage pollution. The physiology and nutrient pulse mechanisms of exploitation by some algae may explain their successful colonization on an overfeed reef. Nelson (1985) demonstrated that photosynthesis of G. crassa is immediately enhanced by exposure to concentrations of dissolved ammonia up to $10 \mu \mathrm{M}$. Since the Gracilaria sp. patches mostly settle on the rubble located below Stegastes nigricans territories, these macrophytes could immediately take up brief pulses of dissolved ammonia excreted by fish $(10 \mu \mathrm{M}$ of ammonia can be expected within or near schools of coral reef fishes; Nelson 1985). These defended sites and their algal turfs are assumed to have an important role in reef trophodynamics (Klumpp \& Polunin 1989) as the resident species may return substantial amounts of nutrients to the defended site by excretion and defecation (Polunin \& Koike 1987). Furthermore, it has been shown that some of these Gracilaria spp. have the ability to store nitrogen that is used after the nutrient pulse has been depleted (Ryther et al. 1981, Bird et al. 1982).

Colonization of living coral substrata by Stegastes nigricans turfs may have another origin. The overgrown corals are settled systematically close to damselfish territories. Peters (1984) reported that on 3 Caribbean reefs, coral colonies were heavily infested with algal turfs developed by territorial damselfish (principally Eupomacentrus dorsopunicans). Kaufman (1977) observed that E. planifrons continuously remove coral tissue to provide a bare substratum which can be colonized by algal turfs. Normally, tissue may regenerate to cover small lesions very quickly (Bak \& Steward-van Eys 1980), except if the coral is weak and algal growth is enhanced by nutrient enrichment (turfs are known to have a production 10- to 20-fold more important than macrophytic algae; Doty 1971). Thus, coral skeleton temporarily bared by tissue lesions can be rapidly colonized by algal filaments. On La Saline reef, summer observations of algal filaments regularly scattered on previously living coral colonies which are established at the limit of S. nigricans territories suggest that coral tissue could have been injured in the same way and, from December to February, can no longer withstand filamentous algal growth.

In Hawaii, Littler (1973) showed that sewage stimulates the growth of various coralline algae at the expense of coral growth. Ogden (1988) reported the suppression of coral reef accretion in favour of calcareous algae as a result of elevated nutrient concentrations in the western Caribbean and in the Pacific.

Banner (1974) and Smith et al. (1981) reported that in the sewage-affected Kaneohe Bay (Hawaii), Dictyosphaeria cavernosa competed by overgrowing and eventually killing coral colonies. On La Saline reef, $D$. cavernosa remained inconspicuous, although widespread on the shaded parts of the coral colonies. 
At Panama, Kilar (1984) reported that the optimum temperature for Acanthophora spicifera productivity is ca $25^{\circ} \mathrm{C}$, which is far lower than the summer temperatures of the La Saline back reef zone waters $\left(27\right.$ to $\left.31^{\circ} \mathrm{C}\right)$ where this alga flourishes. However, Kilar \& Norris (1988) observed that elevated water temperatures accompany periods of low water, where algae tend to 'dissolve' in the seawater after prolonged exposure to air, which is not the case at La Saline reef where the A. spicifera facies disappears after hurricane swells.

The greatest coral mortality $(97 \%)$ occurred on a reef flat area situated between 100 and $180 \mathrm{~m}$ from the reef edge. Least coral mortality was observed in a nonemerging zone of scattered coral heads with very low algal cover $(<5 \%)$. Several hypotheses can be suggested to explain these differences: at low tide, SGD is sucked off from the beach to a break in the reef situated close to the transect (Groove 3 in Cuet et al. 1988). Thus, the nutrient-enriched waters of the back reef zone exit the lagoon rapidly and a part thereof enters back into the reef by the reef crest. Then, at low tide, these nutrient-enriched waters can be ponded on the reef flat by the scouring action of the draining gutter water, while the zone of scattered coral heads remains free from nutrients. Alternatively, the groundwater level in basaltic formations may emerge on the reef flat (Join et al. 1988) and then directly pollute the coral communities. However, this groundwater level is not known to be highly nutrient-enriched (Join pers. comm.). Alternatively, biological factors can be involved: even at high nutrient levels, macroalgae can reach their maximum standing stock only if herbivores are reduced (Littler \& Littler 1985). Chabanet (unpubl.) showed that on the studied reef flat, which is characterized by a high density of macroalgae, scarids (Scarus sp.) and acanthurids (Acanthurus nigrofuscus, A. triostegus, Ctenochaetus striatus, Naso unicornis) are much more abundant than on a nondegraded La Saline reef flat defined by Cuet et al. (1988). Chabanet's study confirms the results of Letourneur (1992) showing that herbivorous fish density is related to algal coverage. $N$. unicornis is well-known as a consumer of leathery macroalgae (Harmelin-Vivien 1979) while other acanthurids feed more on algal turf and/or on detritus, and scarids are removers of turf from hard substrata (Choat 1991). In addition, echinoid density is very low on the studied degraded reef flat (few ind $\mathrm{m}^{-2}$ ), particularly the 'deep-grazers' Diademidae, whereas the density of echinoids can reach 45 ind. $\mathrm{m}^{-2}$ (mostly Echinometra mathaei with Diadema setosum and Echinothrix calamaris) on the non-degraded reef flat. But, during the 1970s (before degradation), Diademidae density was known to be important on the studied reef flat (Faure pers. comm.). Thus, it seems unlikely that the studied reef flat is undergrazed by urchins.
In conclusion, on this exposed reef, high standing crops of algae correspond mostly to a synergy between high nutrient levels and hydrological factors which either limit or favour algal growth and thereby the impact of algal communities on biobuilders. Biological factors such as undergrazing (Ogden \& Lobel 1978) can interfere to a certain extent: although Hatcher (1981) found no significant correlation between grazing pressure and algal standing crop, Hughes et al. (1987) showed that the mass mortality of Diadema antillarum in the Caribbean, coupled with overfishing, induced an increase of the algal biomass on Jamaican reefs.

\section{Decline in coral cover}

Coral mortality $(19 \%$ of the total cover, $16 \%$ by fleshy, filamentous and calcareous algal overgrowing), occurs during low-energy conditions in summer (December to February). In autumn (March to May). corals continue to be stressed by lithophytic algae, but are not overgrown as occurs in the summer. The low turnover of the water favours an increase in water temperature combined with a salinity decrease due to chronic SGD (rainy season) (Cuet 1989). Most nutrients incorporated into algal organic material fall to the lagoon floor as organic detritus, and they subsequently decompose and return to the water column.

The overgrowing of corals by algae during the hot season implies a biotic disruption and/or a weakening of the defense ability of the scleractinians which are highly adapted to nutrient-deficient environments. Davies (1984) calculated that, in conditions of nutrient inputs, Zooxanthellae can produce more carbon by photosynthesis than the hermatypic coral host can utilize. That excess carbon is shed as mucus. Bacterial blooms in the mucus (Mitchell \& Chet 1975) could injure corals by oxygen depletion, by accumulation of sulfide poisons at the coral surface below the mucus layer and by predation on weakened polyps (Garrett \& Ducklow 1975, Ducklow \& Mitchell 1979). Furthermore, endolithic Cyanophyceae (mostly Lyngbya majuscula and Lyngbya sp.) are present immediately below the living tissue within a coral skeleton; it would seem reasonable to expect that penetration of the material by numerous algal filaments would result in some weakening of the coral matrix (Cribb 1973). Risk \& Müller (1983) found $\mathrm{PO}_{4}{ }^{3-}$ to be $5 \times$ higher and $\mathrm{NO}_{3}{ }^{-}$almost $10 \times$ higher inside corals than in the surrounding waters. Thus, calcification of coral colonies could be affected by incorporation of phosphorus into the skeleton associated with detritus deposition on tissue lesions, or as inclusion via endolithic algae which are present within the skeleton, immediately below the living coral tissue (Dodge et al. 1984). 
Moreover, authors have argued that since corals live close to their lethal temperature, they are particularly susceptible to temperature stress (Johannes 1975). Bleaching, first recorded at the study sites by Guillaume et al. (1983), seems to affect these coral communities each summer, and particularly affects colonies of the genus Acropora (Naim unpubl. data). On the transect studied, $3 \%$ of the total coral cover was bleached during summer and did not recover. It must be emphasized that Pocillopora damicornis and Porites (Synaraea) iwayamaensis are not affected by bleaching. In Hawaii, the former is a reef-flat species (Stimson 1978) recognized to be opportunistic (Wallace \& Bull 1981, Wallace 1985) but nevertheless particularly susceptible to temperature increase (Glynn 1984). This suggests that summer bleaching observed on La Saline reef is not caused by the temperature increase. This correlates with the period of depressed coral growth and bleaching events that indicate a physiological stress of many coral species (Oliver 1985).

Otherwise, on the reef flat, the relatively constant algal cover observed during the year strongly suggests that a fundamental shift occurred within the structure of the benthic community. Reef flats are regularly subjected to considerable fluctuations of physical parameters. In the summer of $1982-83$, a series of extremely low tides occurred on La Saline reef. The mass mortality resulting from this low tide period reopened new space for settlement of larvae and spores. For settling coral larvae, the physical structure of the substratum has been shown to be an important factor in determining the abundance of corals (Carleton \& Sammarco 1987). With chronic nutrient enrichment of the surrounding waters, the faster-growing fleshy algae might have been strongly enhanced and the recruitment and growth of slower-growing corals depressed by competition for space (Birkeland 1977). Thus, by precipitating a shift between alternate stable rates, eutrophication may have had significant secondary effects on structures of the reef-flat communities (Lighty 1982, Hatcher 1984). The constant macroalgal dominance on the reef flat may be one stage following the clearing of space by corals after the occurrence of a severe low tide.

\section{CONCLUSION}

On a fringing reef subjected to eutrophic stress under conditions of severe pressure of coastal development, the hot season is the most critical time for scleractinian populations. During this period, environmental conditions change rapidly, and competition with algae is intense. From the 1970 s to the present, La Saline reef flats have gradually been transformed from coral-rich areas into algal-covered banks. This environmental shift has resulted in reduced aesthetic and recreational values of this highly frequented reef of La Réunion Island.

Nutrient inputs from terrestrial drainage, atmospheric deposition and urban discharges may increase progressively in shallow coastal coral-reef areas. These ecosystems must then be regarded as being at risk from eutrophication, which inflicts chronic and often insidious stress on the reef, with consequently potentially damaging effects on both inshore fisheries and recreational facilities. Thus, there is an urgent need to understand the risk and to evaluate all the causes, effects and modalities of action of eutrophication as a prelude to establishing adequate measures of prevention and control.

Acknowledgements. I thank the following colleagues for taxonomical determinations: Dr Th. Le Campion (cyanophytes), Dr C. E. Payri (fleshy algae), Dr J. Vacelet (sponges), Pr G. Faure (corals). I also thank Dr P. Cuet, Dr M. J. Risk, Dr P. W. Sammarco and 3 anonymous reviewers for critically reviewing the manuscript. This research was financially supported by the Conseil Régional and the Conseil Général de la Réunion and by the C.O.R.D.E.T (French Ministry of Overseas Departments and Territories).

\section{LITERATURE CITED}

Atkinson, M. J. (1988). Are coral reefs nutrient-limited? Proc. 6th int. coral Reef Symp. 1: 157-166

Bak, R. P. M., Steward-Van Eys, Y. (1980). Regeneration of superficial damage in the scleractinian corals Agaricia aqaricites $f$. purpurea and Porites astreoides. Bull. mar. Sci. 30: 883-887

Banner, A. H. (1974). Kaneohe Bay, Hawaii: urban pollution and a coral reef ecosystem. Proc. 2nd int. Symp. coral Reefs 2: 685-702

Barnes, J., Bellamy, D. J., Jones, D. J., Whitton, B. A., Drew, E. A., Kenyon, L., Lythgoe, J. N., Rosen, B. R. (1971). Morphology and ecology of the reef front of Aldabra. Symp. zool. Soc. Lond. 28: 87-114

Battistini, R., Bourrouilh, F., Chevalier, J.-P., Coudray, J., Denizot, M., Faure, G., Fisher, J.-C., Guilcher, A., HarmelinVivien, M., Jaubert, J., Laborel, J., Montaggioni, L. F., Masse, J.-P., Maugé, L.-A., Peyrot-Clausade, M., Pichon, M., Plante, R., Plaziat, J.-C., Plessis, Y. B., Richard, G., Salvat, B., Thomassin, B. A., Vasseur, P., Weydert, P. (1975). Éléments de terminologie récifale Indo-Pacifique. Téthys $7(1): 1-111$

Bell, P. R. F. (1992). Eutrophication and coral reefs. Some examples in the Great Barrier Reef lagoon. Wat. Res. 26(5): 553-568

Benayahu, Y., Loya, Y. (1977). Space partitioning by stony corals, soft corals and benthic algae on the coral reefs of the northern Gulf of Eilat (Red Sea). Helgoländer wiss. Meeresunters. 30: 362-382

Benzecri, J. P. (1973). L'analyse des données. II. L'analyse des correspondances. Dunod, Paris, p. 1-619

Bird, K. T., Habig, C., De Busk, T. (1982). Nitrogen allocation and storage patterns in Gracilaria tikvahiae (Rhodophyta). J. Phycol. 18: 344-348 
Birkeland, C. (1977). The importance of rate of biomass accumulation in early successional stages of benthic communities to the survival of coral recruits. Proc. 3rd int. Symp. coral Reefs 1.15-21

Bouchon, C. (1981). Quantitative study of the scleractinian coral communities of a fringing reef of Reunion lsland (Indian Ocean). Mar. Ecol. Prog. Ser. 4: 273-288

Bouchon, C., Bouchon-Navaro, Y (1981). Etude d'environnement du lagon du récif de l'Hermitage (lieu-dit: Go Payet). Rapport interne, Lab. Biol. mar., Univ. Réunion, p. $1-33$

Bradbury, R. H., Loya, Y., Reichelt, R. E., Williams, W. T (1986). Patterns in the structural typology of benthic communities on two coral reefs of the Central Great Barrier Reef. Coral Reefs 4: 161-167

Brown, B. E., Howard, L. S. (1985). Assessing the effects of 'stress' on reef corals. In: Baxter, J. H. S., Yonge, M. (eds.) Advances in marine ecology. Academic Press, London, Vol. 22, p. 1-63

Carleton, J. H., Sammarco, P. W. (1987). Effects of substratum irregularity on success of coral settlement: quantification by comparative geomorphological techniques. Bull. mar. Sci. 40: 85-90

Choat, J. H. (1991). The biology of herbivorous fishes on coral reefs. In: Sale, P. F. (ed.) The ecology of fishes on coral reefs. Academic Press, New York, p. 120-155

Cribb, A. B. (1973). The algae of the Great Barrier Reefs. In: Jones, O. A., Endean, R. (eds.) The biology and geology of coral reefs. Academic Press, New York, Vol. 2, p. 47-73

Crossland, C. J. (1983). Dissolved nutrients in coral reef waters. In: Barnes, D. J. (ed.) Perspectives on coral reefs. Brian Clouston Publ., AIMS, Townsville, p. 56-68

Cuet, P. (1989). Influence des résurgences d'eau douce sur les caractéristiques physico-chimiques et métaboliques de l'écosystème récifal à La Réunion. Doct. de Spécialité en Chimie marine, Univ. Aix-Marseille III, p. 1-204

Cuet, P., Naim, O., Faure, G., Conan, J.-Y. (1988). Nutrientrich groundwater impact on benthic communities of La Saline fringing reef (Réunion Island, Indian Ocean): preliminary results. Proc. 6th int. coral Reef Symp. p. $207-212$

Davies, P. S. (1984). The role of Zooxanthellae in the nutritional energy requirements of Pocillopora eydouxi. Coral Reefs 2: 181-186

D'Elia, C. F., Webb, K. L., Porter, J. W. (1981). Nitrate-rich groundwater inputs to Discover Bay, Jamaica; a significant source of $\mathrm{N}$ to local coral reefs? Bull. mar. Sci. 31(4): $903-910$

Dodge, R. E., Jickells, T. D., Knap, A. H., Boyd, S., Bak, R. P. M. (1984). Reef-building coral skeletons as chemical pollution (phosphorus) indicators. Mar. Pollut. Bull. 15(5) $178-187$

Done, T J., Dayton, P. K., Dayton, A. E., Steger, R. (1991). Regional and local variability in recovery of shallow coral communities: Moorea, French Polynesia and central Great Barrier Reef. Coral Reefs 9(4): 183-192

Doty, M. S. (1969). The ecology of Honaunau Bay, Hawaii. Hawaii Bot. Sci. Paper 14, Univ. of Hawaii, p. 1-221

Doty, M. S. (1971). Physical factors in the production of tropical benthic marine algae. In: Costlow, J. D. (ed.) Fertility of the sea. Gordon \& Breach, New York, Vol. 1, p. 99-121

Drew, E. (1977). A photographic survey down the seaward reef front of Aldabra atoll. Atoll Res. Bull. 193: 1-7

Ducklow, H. W. Mitchell, R. (1979). Observations on naturally and artificially diseased tropical corals: a scanning electron microscope study. Microb. Ecol. 5: 215-233

Faure, G. (1982). Recherche sur les peuplements de Sclérac- tiniaires des récifs coralliens de l'Archipel des Mascareignes (Océan Indien Occidental). Doct. ès Sciences, Univ. Aix-Marseille II, Vol. 1, p. 1-206

Fishelson, L. (1973). Ecology of coral reefs in the Gulf of Aqaba (Red Sea) influenced by pollution. Oecologia 12: $55-67$

Garrett, P., Ducklow, H. (1975). Coral diseases in Bermuda. Nature 253: 349-350

Glynn, R. W. (1984). Widespread coral mortality and the 1982/83 El Niño warming event. Environ. Conserv. 11: 133-146

Guillaume, M., Payri, C. E., Faure, G. (1983). Blatant degradation of coral reefs at La Réunion Island (West Indian Ocean). Int. Soc. for Reef Studies, Nice (abstract)

Hallock, P. (1988). The role of nutrient availability in bioerosion: consequences to carbonate buildups. Palaeogeogr., Palaeoclimatol., Palaeoecol. 63: 275-291

Hallock, P., Schlager, W. (1986). Nutrient excess and the demise of coral reefs and carbonate platforms. Palaios 1: 389-398

Harmelin-Vivien, M. (1979). Ichtyofaune des récifs coralliens de Tuléar: écologie et relations trophiques. Doct. ès Sciences, Univ. Aix-Marseille II, p. 1-165

Hatcher, B. G. (1981). The interaction between grazing organisms and the epilithic algal community of a coral reef: a quantitative assessment. Proc. 4 th int. Symp. coral Reefs 2: 515-524

Hatcher, B. G. (1984). A maritime accident provides evidence for alternate stable states in benthic communities on coral reefs. Coral Reefs 3: 199-304

Hughes, T. P., Reed, D. C., Boyle, M.-J. (1987). Herbivory on coral reefs: community structure following mass mortalities of sea urchins. J. exp. mar. Biol. Ecol. 113: $39-59$

Johannes, R. E. (1975). Pollution and degradation of coral reef communities. In: Ferguson Wood, E. J., Johannes, R. E. (eds.) Tropical marine pollution. Elsevier oceanography ser., No. 12, New York, p. 13-51

Johannes, R. E. (1980). The ecological significance of the submarine discharge of groundwater. Mar. Ecol. Prog. Ser. 3: 365-373

Join, J. L., Pommé, J. B., Coudray, J., Daesslé, M. (1988). Caractérisation des aquifères basaltiques en domaine littoral. Impact d'un récif corallien. Hydrogéologie 2: $107-115$

Kaufman, L. (1977). The three-spot damselfish: effects on benthic biota of Caribbean coral reefs. Proc. 3rd int. Symp. coral Reefs 1: 559-564

Kilar, J. A. (1984). Ecological studies of the alga Acanthophora spicifera (Vahl) Borg. (Rhodophyta, Ceramiales). Ph. D. thesis, Dalhousie Univ

Kilar, J. A., Norris, J. N. (1988). Composition, export, and import of drift vegetation on a tropical, plant-dominated, fringing-reef platform (Caribbean Panama). Coral Reefs 7 . 93-103

Kinsey, D. W., Davies, P. J. (1979). Effects of elevated nitrogen and phosphorus on coral reef growth. Limnol. Oceanogr. 24: $935-940$

Klumpp, D. W., Polunin, N. V. C. (1989). Partitioning among grazers of food resources within damselfish territories on a coral reef. J. exp. mar. Biol. Ecol. 125: 145-169

Kohout, F. A., Kolipinski, M. C. (1967). Biological zonation related to groundwater discharge along the shore of Biscayne Bay, Miami, Florida. In: Lauff, G. H. (ed.) Estuaries Am. Assoc. Adv. Sci. 83: 488-499

Leroy, C., Barbaroux, O. (1980). Observations physiques et chirniques effectuées sur le milieu marin autour de l'île 
de la Réunion. Rapport interne, IFREMER Nantes, p. 1-62

Letourneur, Y (1992). Dynamique des peuplements ichtyologiques des platiers récifaux de l'île de la Réunion Doct. de Spécialité en Océanologie biologique, Univ. AixMarseille II, p. 1-244

Lewis, J. B. (1985). Groundwater discharge onto coral reefs, Barbados, West Indies. Proc. 5th int. coral Reef Congr. 6: $477-481$

Lewis, J. B. (1987). Measurements of groundwater seepage flux onto a coral reef: spatial and temporal variations. Limnol. Oceanogr. 32(5): 1165-1169

Lewis, J. B. (1988). Nutrients and the productivity of coral reef ecosystems. In: Pomsroy, L. R., Alberts, J. J. (eds.) Concepts of ecosystem ecology, Ecological Studies 67. SpringerVerlag, New York, p. 367-387

Lighty, R. G. (1982). Fleshy algal domination of a modern Bahamian barrier reef: example of an alternate climax reef community. Proc. 4th int. Symp. coral Reefs 1: 722 (abstract)

Littler, M. M. (1973). The population and community structure of Hawaiian fringing reef crustose Corallinaceae (Rhodo. phyta: Cryptonemiales). J. exp. mar. Biol. Ecol. 11: 103-120

Littler, M. M., Littler, D. S. (1985). Factors controlling relative dominance of primary producers on biotic reefs. Proc. 5th int. coral Reef Congr. 4: 35-39

Maragos, J. E., Evans, C., Holthus, P. (1985). Reef corals in Kaneohe Bay 6 years before and after termination of sewage discharges (Oahu, Hawaiian archipelago). Proc. 5th int. coral Reef Congr. 4: 189-194

Mergner, H. (1981). Man-made influences on and natural changes in the settlement of the Aqaba reefs (Red Sea). Proc. 4th int. Symp. coral Reefs 1: 193-207

Mitchell, R., Chet, I. (1975). Bacterial attack of corals in polluted seawater. Microb. Ecol. 2: 227-233

Montaggioni, L. F., Faure, G. (1980). Les récifs coralliens des Mascareignes (Océan Indien). Coll. travaux du Centre universitaire, Univ. Réunion, p. 1-151

Morton, J (1974). The coral reefs of the British Solomon Islands: a comparative study of their composition and ecology. Proc. 2nd int. Symp. coral Reefs 2: 31-53

Nelson, S. G. (1985). Immediate enhancement of photosynthesis by coral reef macrophytes in response to ammonia enrichment. Proc. 5th int. coral Reef Congr. 5: 65-70

Ogden, J. C. (1988). The influence of adjacent systems on the structure and function of coral reefs. Proc. 6th int. coral Reef Symp. 1: 123-129

Ogden, J. C., Lobel, P. S. (1978). The role of herbivorous fishes and urchins in coral reef communities. Environ. Biol. Fish 3(1): $49-63$

Oliver, J. K. (1985). Recurrent bleaching and mortality of corals on the Great Barrier Reef. Proc. 5th int. coral Reef Congr. 4: 201-206

Pastorok, R. A., Bilyard, G. R. (1985). Effects of sewage pollution on coral reef communities. Mar. Ecol. Prog. Ser. 21: $175-189$

This article was presented by $M$. Pichon, Townsville, Australia
Payri, C. E. (1983). Etude d'environnement des récifs de la Saline et de Saint-Leu. Etude qualitative et quantitative des Macrophytes. Rapport interne, Lab. Biol. mar., Univ. Réunion, p. 12

Payri, C. E. (1985). Contribution to the knowledge of the marine benthic flora of Reunion Island (Mascarene Archipelago, Indian Ocean). Proc. 5th int. coral Reef Congr 6: $635-640$

Payri, C. E. (1987). Zonation and seasonal variation of the commonest algae on Tiahura reef (Moorea Island, French Polynesia). Bot. Mar. 30: 141-149

Peters, E. C. (1984). A survey of cellular reactions to environmental stress and disease in Caribbean scleractinian corals. Helgoländer Meeresunters. 37: 113-137

Polunin, N. V. C., Koike, I. (1987). Temporal focusing of nitrogen release by a periodically feeding reef fish. J. exp. mar. Biol. Ecol. 111: 285-296

Reichelt, R. E., Loya, Y., Bradbury, R. H. (1986). Patterns in the use of space by benthic communities on two coral reefs of the Great Barrier Reef. Coral Reefs 5: 73-79

Risk, M. J., Müller, H. R. (1983). Porewater in coral heads: evidence for nutrient regeneration. Limnol. Oceanogr. 28(5): $1004-1008$

Rose, C. S., Risk, M. J. (1985). Increase in Cliona delithrix infestation of Montastrea cavernosa heads on an organically polluted portion of the Grand Cayman fringing reef. Mar. Ecol, 6(4): 345-363

Ryther, J. H., Corwin, N., De Busk, T. A., Williams, L. D. (1981). Nitrogen uptake and storage by the red alga Gracilaria tikvahiae (McLachlan 1979). Aquaculture 26; 107-115

Smith, S. V., Kimmerer, W. J., Laws, E. A., Brock, R. E., Walsh, T. W. (1981). Kaneohe Bay sewage diversion experiment: perspectives on ecosystem responses to nutritional perturbation. Pacif. Sci. 35(4): 279-395

Stimson, J. S. (1978). Mode and timing of reproduction in some common hermatypic corals of Hawaii and Enewetak. Mar. Biol. 4: 173-184

Tomascik, T., Sander, F. (1985). Effects of eutrophication on reef-building corals. I. Growth rate of the reef-building coral Montastrea annularis. Mar. Bio]. 87: 143-155

Tomascik, T., Sander, F. (1987). Effects of eutrophication on reef-building corals. II. Structure of scleractinian coral communities on fringing reefs, Barbados, West Indies. Mar. Biol. 94: 53-75

Tsuda, R. T. (1974). Seasonal aspects of the Guam Phaeophyta (brown algae). Proc. 2nd int. Symp. coral Reefs 1: 43-47

Walker, D. I., Ormond, R. F. G. (1982). Coral death from sewage and phosphate pollution at Aqaba, Red Sea. Mar. Pollut. Bull. 13(1): 21-25

Wallace, C. C. (1985). Seasonal peaks and annual fluctuations in recruitment of juvenile scleractinian corals. Mar. Ecol. Prog. Ser. 21: 289-298

Wallace, C. C., Bull, G. D. (1981). Patterns of juvenile coral recruitment on a reef front during a spring-summer spawning period. Proc. 4th int. Symp. coral Reefs 2: $345-350$

Manuscript first received: January 16, 1990

Revised version accepted: May 10, 1993 